\title{
Billaea rhynchophorae, a palm weevil parasitoid with global potential
}

\author{
Bernhard Löhr' ${ }^{1}$, Aldomario Negrisoli ${ }^{2}$ and Juan Pablo Molina ${ }^{1}$ \\ (1) Colombian Corporation of Agricultural Research, Palmira Research Center, Palmira, Cauca Valley, Colombia; \\ (2) Brazilian Agricultural Research Corporation, Coastal Tablelands, Sergipe, Brazil.
}

\begin{abstract}
Löhr, B., A. Negrisoli and J.P. Molina. 2019. Billaea rhynchophorae, a palm weevil parasitoid with global potential. Arab Journal of Plant Protection, 37(2): 101-108.

The American palm weevil, Rhynchophorus palmarum, is the main primary pest of palms in tropical America and the principal vector of the red ring disease, the major phytosanitary problem of coconut and oil palm in South America. The current management of the problem is based on the capture of adult weevils with aggregation pheromone and the elimination of diseased palms, a system difficult to implement for smallholder producers. Biocontrol agents of the weevil, the tachinid parasitoids Billaea spp., are known with limited distribution in Bahía State of Brazil. Their introduction and release in affected areas could greatly improve the natural control of the weevils. Furthermore, these parasitoids are known to attack palm-boring weevils in five different genera and could be a new control option for the red palm weevil, Rhynchophorus ferrugineus, the worst pest of palms worldwide. The collection, rearing and study of these parasitoids for introduction in new areas are the aim of this study. A detailed analysis of the necessary steps to comply with regulatory aspects and a research programme to ensure biosafety is described.
\end{abstract}

Keywords: Palm weevils, Rhynchophorus palmarum, R. ferrugineus, tachinid parasitoids, Billaea rhynchophorae, host range, risk analysis.

\section{Introduction}

Three palm species dominate commercial palm production in South America: African oil palm (Elaeis guineensis Jacq.), coconut (Cocos nucifera L.) and peach palm (Bactris gasipaes Kunth) for production of palm hearts and fruits. All suffer from attack by the American or black palm weevil (APW), Rhynchophorus palmarum (L.) (Coleoptera, Dryophthoridae) and a number of other weevil species with varying degree of damage according to the location (Moura, 2017). The American palm weevil is also the major vector for Bursaphelenchus cocophilus (Nematoda: Aphelenchidae), which causes the red ring disease (RRD) of coconut and oil palm (Chinchilla, 1991). The APW/RRD complex is particularly serious at the southern Pacific coast of Colombia, where it causes recurrent pandemics that periodically destroy entire coconut plantations along the rivers flowing into Tumaco Bay (Löhr, 2013)

Due to their development within the stem of palms, palm weevil larvae and pupae are largely protected against the attack of natural enemies. At the international level, very little is known about natural enemies of stem-boring palm pests that exert an appreciable degree of natural control. (Murphy and Briscoe, 1999) and more recently, Ortega et al. (2017) reviewed the biological control options of the red palm weevil (RPW) and listed several control agents, especially fungi and entomopathogenic nematodes. However, these alternatives present problems in their use, such as the availability of formulated products for farmers and the difficulty of application in adult palms. A biocontrol option that has been overlooked but seems to be the most promising of all natural enemies of palm weevils known so far are parasitoid flies of larvae and pupae (Löhr, 2013): Billaea menezesi (Townsend) (Diptera: Tachinidae) was identified more than 25 years ago in oil palm in southern Bahia/Brazil, where parasitism rates up to $72 \%$ have been reported (Moura et al., 1993). More recently, Billaea rhynchophorae (Blanchard, 1937) was registered as palm weevil parasitoid in the same area on oil palm and a native palm species, Attalea funifera Martius (Arecaceae) (Moura et al., 2006).

A new threat to the palm industries in South America is the arrival of the red palm weevil (RPW), Rhynchophorus ferrugineus Olivier (Coleoptera: Dryophthoridae) via the importation of infested date palms to the Dutch Antilles in 2008 (Kairo, 2010). The red palm weevil has a long history of invasions, first to the Middle East resulting in huge losses (El Sabea et al., 2009), then the Mediterranean (Barranco et al., 1995), China (Ju and Ajlan, 2011), Japan (Aman, 2001), and Malaysia (Azmi et al., 2013) and hence has to be taken seriously. Even though the problem at present seems to be limited to the Dutch Antilles, their proximity to the South American continent could facilitate its spread. Hoddle et al. (2015) demonstrated in flight mill studies that RPW has the capacity to fly up to $50 \mathrm{~km}$ in a day, double the distance of Aruba to the continent.

Here we analyse the current situation and present an action plan for the control of the American palm weevil and to prevent an invasion by the red palm weevil. We also analyse the possibilities for the use of the parasitoids in nontropical areas affected by palm weevils and propose ways for their integration in IPM programs.

\section{Identification of Local Mortality Factors in Colombia}

Before embarking on an introduction biocontrol project, the local natural enemies of the target species should be known. Studies conducted in Colombia identified a larval predator, Hololepta sp. (Coleoptera: Histeridae), very common at the Pacific Coast and the Eastern Plains. However, due to its small size $(3 \mathrm{~mm})$ its value as palm weevil predator is 
doubtful and it is probably more interested in the thousands of sarcophagid fly larvae that are invariably found in decomposing palm stems. Another histerid predator, Oxysternus maximus L. was first reported by Fanny Alvañil at Cumaral/Meta in Colombia (Posada et al., 1990). Large numbers of this species were collected in an abandoned, bud rot diseased oil palm plantation at Acacías/Meta (Löhr, unpublished). Attempts to multiply the species were given up when the females produced only one egg per week $(\mathrm{G}$. León, personal communication). This species was later also found in very low numbers at the Pacific coast (G. León, personal communication). Several entomopathogenic fungi have also been identified, mostly Beauveria bassiana Vuillemin and Metarhizium anisopliae (Metschnikoff) Sorokin (Aldana et al., 2010, 2011).

Fly puparia have been recorded with cocoons of $R$. palmarum in Colombia on two occasions: the palm weevil management handbook of the National Center of Palm Research mentions four fly puparia found in Tumaco in oil palm (Aldana et al., 2011). A single fly emerged and escaped before being identified (R. Aldana, personal communication). And in a sample of 713 large larvae and cocoons, Ramirez (1998) found a single fly puparium that could not be identified either. In later surveys in Guapi, Timbiquí, Tumaco Bay and in the Eastern Plains, with over 370 larvae and pupae examined, the existence of parasitoids could not be confirmed (B. Löhr, unpublished).

\section{An Untested yet Promising Option: the Moura Flies of Brazil}

Alternative biocontrol agents that have not received due attention in the reviews of biocontrol agents (Murphy and Briscoe, 1999; Ortega et al., 2017), are the tachinid parasitoids of APW larvae and pupae, Billaea menezesi (Townsend) and Billaea rhynchophorae (Blanchard) (Diptera: Tachinidae). The former species was identified first more than 25 years ago in the south of Bahia/Brazil, where parasitism rates of up to $72 \%$ were reported (Moura et al., 1993). In a later study, an average $50 \%$ of large larvae and/or pupae were found parasitized in oil palm and Attalea funifera (Mart.), a native palm species of Brazil (Moura et al., 2006). However, in spite of these high parasitism rates, detailed studies on the biology or ecology of these species have never been conducted, nor have introductions to new geographical areas been attempted as was recommended in Moura's first publication: "The area of distribution of the fly in South America and also in Africa and Ásia could be augmented for the control of related species" (Moura et al., 1993).

There is a taxonomic confusion regarding this fly since in the first publication, Moura et al. (1993) referred to Paratheresia (now Billaea) menezesi and in the second to Billaea rhynchophorae (Moura et al., 2006). According to Silvio Nihei (personal communication), tachinid taxonomist of the University of São Paulo, the two species names are valid; so there are possibly two species of palm weevil parasitoids in Brazil.

Considering as a starting point the climatic conditions where the species were found in Brazil, areas with similar climatic conditions in the Americas were mapped out using Homologue $^{\mathrm{TM}}$ (Jones et al., 2005).

The results indicated that the parasitoids could be established in the most important coconut and oil palm areas in Colombia and other Latin American countries (Figure 1).

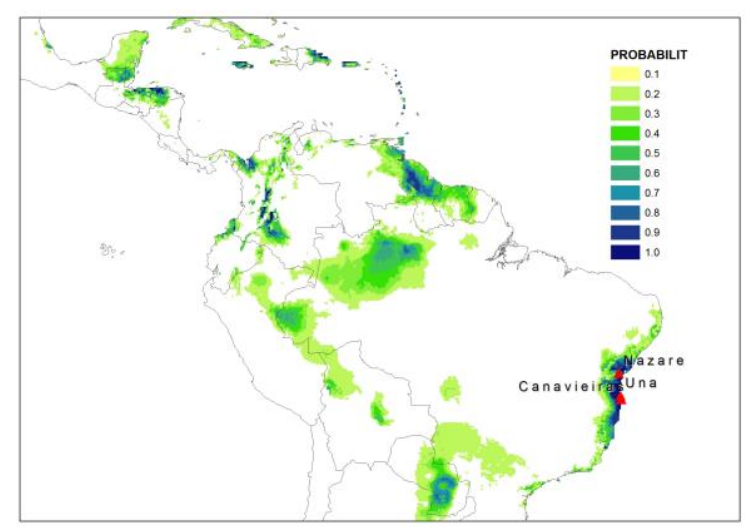

Figure 1. Climate matching chart between area of endemism and possible introduction of Billaea rhynchophorae in the Americas. Red triangles mark the locations where the flies have been collected. Map elaborated using Homologue $\mathrm{e}^{\mathrm{TM}}$ (Jones et al., 2005).

\section{Regulatory Aspects}

Any work in Brazil that involves the collection of specimens by foreign entities can only be done in cooperation with a Brazilian research institution and requires special permits. Furthermore, collection, rearing, research as well as export and import of biological material is subject to the regulations of Brazilian Institute of Environment and Renewable Natural Resources (IBAMA). The Brazilian Government, through IBAMA, provides the SisCites system for requesting, evaluating and issuing licenses for collection, research and eventual export of specimens of Brazilian wildlife. The legally established period for processing licences is 60 days and the validity of licenses is 180 days.

The importation or exportation of fauna is based on the following IBAMA standards: 1) Ibama Ordinance No. 93/1998, that regulates the import and export of live specimens, products and by-products of Brazilian and exotic wildlife; 2) Normative Instruction Ibama No. 140/2006, that establishes the Ibama application and licensing service for the import, export and re-export of specimens, products and by-products of Brazilian wild fauna and flora; and 3) Decree No. 3607 of September 21, 2000, that provides for the implementation of the Convention on International Trade in Endangered Species of Wild Fauna and Flora (CITES), and other measures.

\section{Biology and Ecology of Tachinidae}

The Tachinidae family is one of the largest dipteran families, with more than 8200 described species (Cantrell and Crosskey, 1989), all parasitoids of other arthropods. Tachinids are very common flies and the great majority are parasitoids of lepidopteran larvae (Stireman et al., 2006; Vincent, 1985). The family is subdivided into four (Wood, 1987) or five (Crosskey, 1976) subfamilies according to their 
biology and morphology. The genus Billaea belongs to the Dexiini subfamily which is distinguished by generally large specimens and by incubating its eggs in the oviduct. Females deposit live larvae or eggs that emerge immediately after oviposition (Clausen, 1940).

The fertility of females is generally high and, depending on the species, they produce between 500 and 3000 eggs (O'Hara, 1985). Most species in the subfamily attack plant-boring coleoptera hidden inside the plant tissue (Nihei and Pavarini, 2011). Therefore, females do not have direct contact with their host, but deposit their larvae or eggs onto the frass produced by the larvae of the borers or into the openings of the larval galleries (Arnaud, 1978; Campadelli and Gardenghi, 1991). The emerging planidia have to look actively for their host, following the feeding tunnel in the plant material (Rodriguez del Bosque and Smith, 1996; Suazo et al., 2006). Although there is no detailed information on B. rhynchophorae and B. menezesi, it is expected that they belong to this type of parasitoid.

Despite the first detection of the parasitoid flies more than 25 years ago, to date there is no detailed information on their biology. Fly puparia have mostly been found in pupal cocoons during the elimination of red ring diseased oil palms. This may just be a sampling bias but it could also hint to an endocrinological relationship between parasitoid and host as has been observed in other cases in Tachinidae (Baronio and Sehnal, 1980; Mellini, 1986).

The age of the host larvae is an important factor for the success of the parasitism of Tachinidae (Mellini, 1986, Terkanian, 1993) as well as the number of larvae that attack the host at different ages: an excess of parasitoid larvae results in mortality of part of them or death of the host (Bobadilla, 1992). The viviparous nature of the Moura flies allows for forced inoculation of potential hosts (Figure 2, and Figure 3) or weevil larvae of different ages/weights with different numbers of parasitoid planidia to determine the ideal combination (Gross, 1988; Gross et al., 1985).

\section{Host/Parasitoid Interaction in Different Palm Species}

The host searching behaviour of tachinid flies is largely unknown. Circumstantial evidence indicates that the percentage parasitism by Billaea spp. varies between different palm species with higher rates in oil palm than in coconut or Attalea funifera (J.I. Moura, personal communication).

This may be due to variations in the behaviour of the weevil larvae in different palm species, or to differences in the preference of the flies for kairomones emitted by different palm species. Several studies have shown that tachinid species are able to distinguish between kairomones from different plants (Montieth, 1955, 1963; Roland et al., 1989; Roth et al., 1982) as well as host secretions or frass produced by borers (Clement et al., 1986; Suazo et al., 2006). However, recent data show that a congeneric species, Billaea claripalpis Wulp, indiscriminately parasitizes Diatraea saccharalis F. (Lepidoptera: Crambidae) (a suitable host) and $R$. palmarum (an unsuitable host) larvae in sugarcane when both are offered simultaneously (J. Gaviria, in preparation).

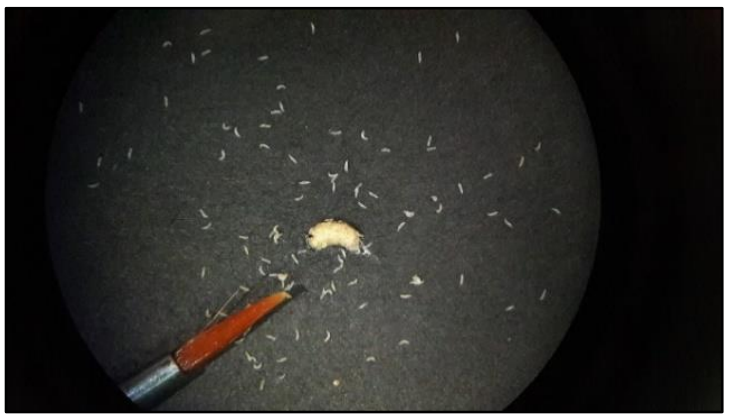

Figure 2. Billaea claripalpis ovary with emerging planidia and brush for transfer of planidia onto a host for host suitability testing

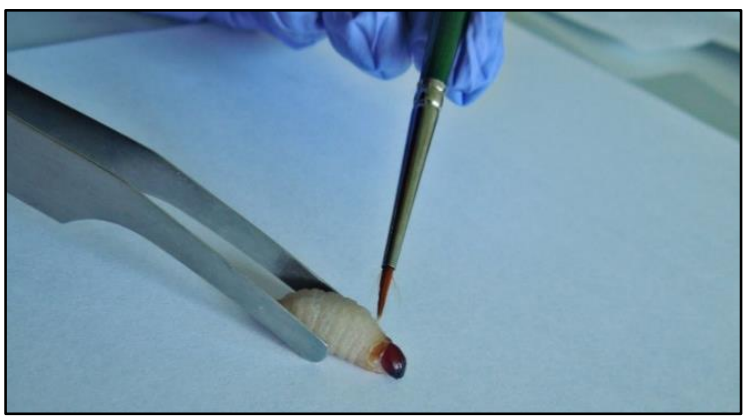

Figure 3. Transfer of Billaea claripalpis planidia to Rhynchophorus palmarum larva for host suitability testing.

\section{Host Range of Billaea spp.}

Host range studies are central to the risk assessment for a parasitoid considered for introduction elsewhere. This is particularly true for Tachinidae species whose host range in general is considerably wider than in other parasitoid families (Eggleton and Belshaw, 1993). Therefore, the first consideration in the case of Billaea is of taxonomic nature: Billaea belongs to the Theresiini tribe of the subfamily Dexiinae that has specialized on coleopterous borer larvae, mainly of the Dryophthoridae family (Nihei and Pavarini, 2011). According to these authors, the only exception is $B$. claripalpis, widely used in Colombia for biological control of the sugarcane borer, D. saccharalis (Vargas, 2015).

The vivipary of the Moura fly facilitates the host range studies by allowing the manual infestation of different potential host species or weevil larvae. The host testing procedure generally starts with species that are taxonomically and ecologically close to the target species (other palm weevils), casting the net wider with every step (lepidopterous palm borers) then lepidopterous palm foliage feeders until the researcher and the authorities are satisfied. Circumstantial evidence indicates that B. rhynchophorae can attack several other weevil palm pests such as Dynamis borassi F., Rhinostomus barbirostris F., Homalinotus coriaceus Gyllenhal and Amerhinus ynca Sahlberg (Moura 
et al., 2002), all of which will be investigated for host suitability.

The next species to be tested is Eupalamides daedalus (F.), (Lepidoptera: Castniidae), an occasionally serious palm-boring lepidopterous species occurring in Pará and Amazonas States of Brazil (Moura, 2017) and a congeneric species (Eupalamides guyanensis Houlbert) is know from the Eastern Plains of Colombia (Aldana et al., 2010). In both cases, efficient natural enemies are not known and an effect of Billaea spp. On this pest might be considered a welcome addition to their list of mortality factors.

Any parasitism outside the group of palm-boring insect species is not acceptable. Considering the known preference of Tachinidae for lepidopterous larvae (Vincent, 1985), a number of lepidopterous foliage-feeding species of palm pests will be studied as alternative hosts: Brassolis sophorae L., a gregarious and Opsiphanes invirae Hübner, a solitary species (both Lepidoptera: Nymphalidae), and Synale hylaspes Stoll (Lepidopter: Hesperidae). The host testing procedure is outlined in Figure 4.

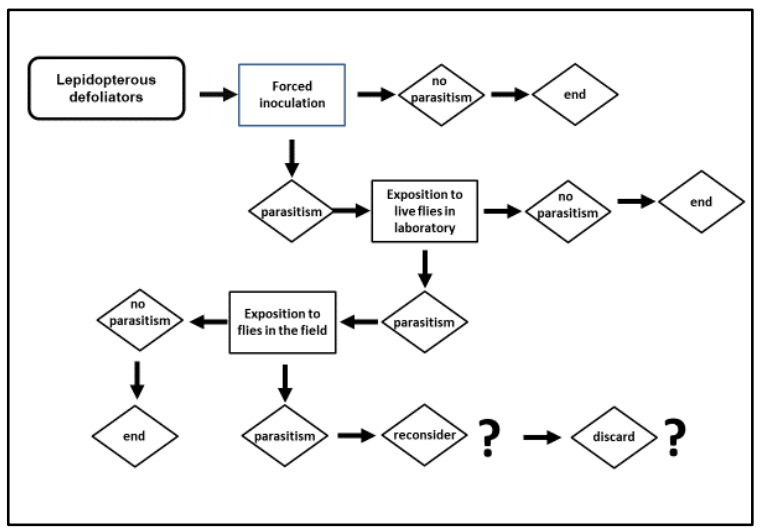

Figure 4. Schematic process of host suitability testing for possible alternative host species of the palm weevil parasitoid Billaea rhynchophorae (Diptera: Tachinidae).

\section{Mass Rearing of Billaea spp.}

In vitro production of biologically and behaviourally normal Tachinidae in complete absence of the host and in artificial diet free of any component coming from hosts has been developed for four species (Dindo and Grenier, 2014) and there is a considerable volume of publications dealing with the different aspects of this process (Dindo et al., 2007, 2006; Bratti and Nettles, 1992; Mellini and Campadelli, 1996). The success of in vitro rearing depends on the biology of the parasitoid and the endocrinological relationship between host and parasitoid, host-dependant parasitoids generally being more difficult to rear on artificial medium (Dindo, 1998; Thompson, 1999). Both are unknown at present, making a prediction for the outcome of these efforts difficult. Nevertheless, a mass rearing system would be very useful in case of an invasion of the red palm weevil in South America. Mass rearing could also facilitate the use of the Moura flies in areas where climatic conditions do not allow permanent establishment, but would allow the use of the flies during favourable periods of the year like the Mediterranean (Figure 5) and the Middle East regions (Figure 6).

\section{Risk Analysis}

The risk analysis will be based on four components: taxonomy, host range tests, adult fly behaviour and fly ecology. The taxonomic position of the genus Billaea in the tribe Dexiini, a grouping of flies with exclusively viviparous or ovoviviparous reproduction and coleopterous hosts is a strong indication of specialization. This is reinforced by the existing host records for the genus Billaea: almost all known hosts are larvae of coleopterous borers of woody plants, the only exception is Billaea claripalpis Wulp, a parasitoid of $D$. saccharalis in sugarcane (Nihei and Pavarini, 2011). The taxonomic information alone is already an indication of high specialization of the Moura flies and consequently a low risk associated with an introduction. Further information will be obtained from the studies of host range, fly biology, and fly behaviour. The analysis of the combined results of these studies will allow a sound judgement of the risk associated with an introduction of the flies into areas where they do not exist at present.
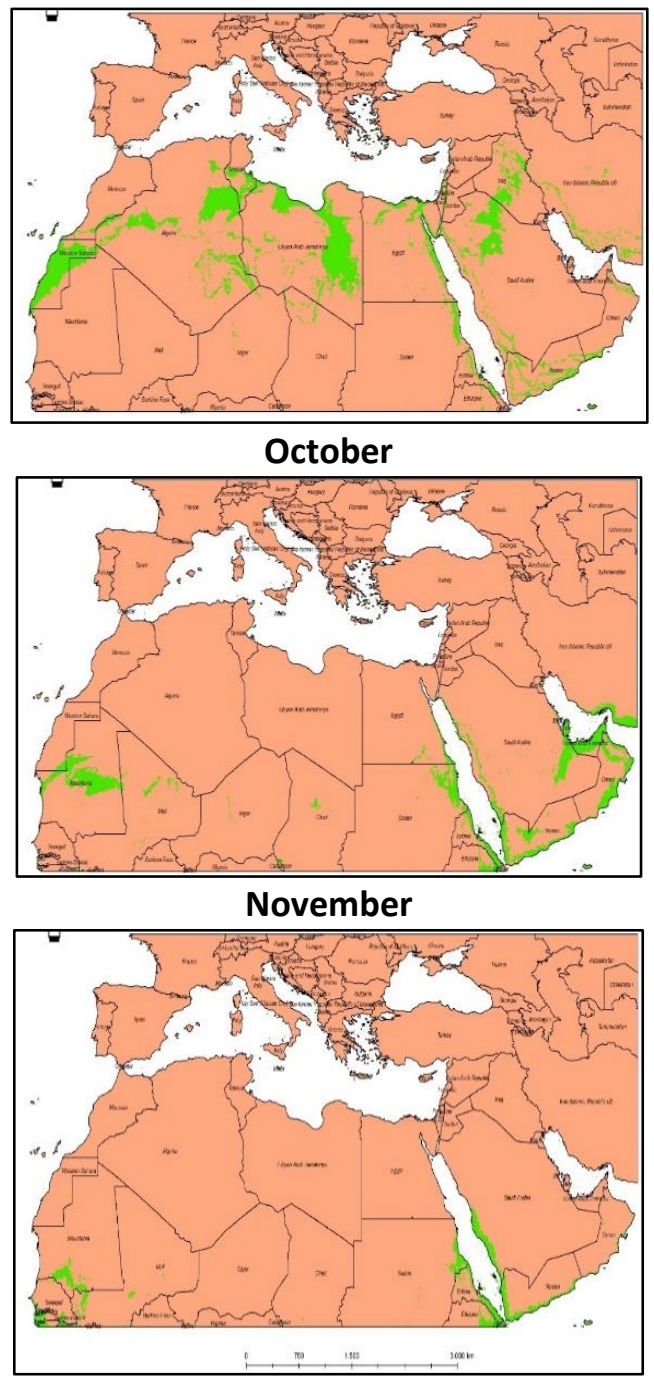

December

Figure 5. Areas (in green) and periods where Brazilian palm weevil parasitoids (Billaea spp.) could be released in the Mediterranean. (Temperature range $17-32^{\circ} \mathrm{C}$, maps developed by Angela Castaño). 

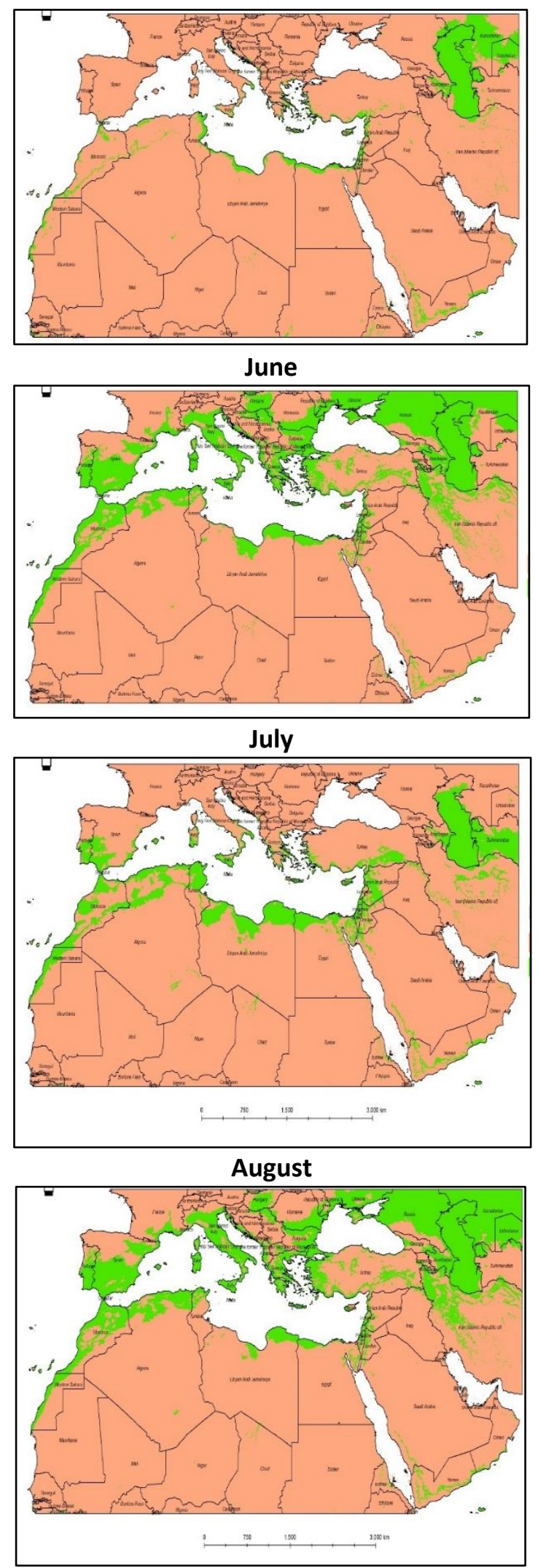

September

Figure 6. Areas (in green) and periods where Brazilian palm weevil parasitoids (Billaea spp.) could be released in the North Africa, Red Sea, Arabian Peninsula and Persian Gulf. (Temperature range $17-32^{\circ} \mathrm{C}$, maps developed by Angela Castaño).

\section{Quarantine and Export Permit for Billaea spp.}

Risk analysis and quarantine processing are the two principal requisites before a parasitoid can be considered for importation. The Brazilian Corporation of Agricultural Research operates quarantine facilities and has qualified staff for quarantine processing of insects at their research station in Jaguariuna/São Paulo. All flies considered for export will have to pass one generation at this station and undergo the necessary screening to ensure no unwanted organisms (hyperparasitoids, diseases and particularly problems of possible transovarial transmission such as microsporidia) accompany the parasitoids. Export permits will be processed by EMBRAPA IP Department.

\section{The Moura Flies and $\boldsymbol{R}$. ferrugineus}

In view of the recent introduction of RPW to the Dutch Antilles and other imminent pest invasions, EMBRAPA organized a symposium on invasive species in Boa Vista/Roraima in May 2015. One of the results of this symposium was the development of a cooperative research programme between EMBRAPA and Corpoica (now AGROSAVIA) to get prepared for an eventual invasion by the red palm weevil by researching possible control methods beforehand. Therefore, the general objective of our initiative is to increase the natural control of APW in areas outside the natural distribution of tachinid weevil parasitoids and to develop control options that can be used in case of an accidental introduction of RPW to the South American continent.

Due to the biological similarity between the black and red palm weevil, it is expected that Billaea spp. will work as a biological control agent against this new pest in the Caribbean islands and thus could be used in an eradication attempt on the islands to avoid an invasion of the South American continent with unpredictable consequences. In addition, the species might be a welcome addition to the control options in other areas affected by $R$. ferrugineus.

To generate maps of areas and seasons suitable for liberations of $B$. rhynchophorae, we used $17^{\circ} \mathrm{C}$ as lower and $32^{\circ} \mathrm{C}$ as upper limit and crossed these with data of the minimum and maximum temperature in multi-year monthly averages published by Fick and Hijmans (2017). The maps were created using $\mathrm{R}$ software, through the functions included in the packages Raster and Tiff, generating an output file for each month. Subsequently, the files generated were loaded into ArcGIS ${ }^{\circledR}$ and ArcMap ${ }^{\mathrm{TM}}$ software and cut to fit the coordinates of the study area. According to this analysis, conditions in the Mediterranean should allow seasonal releases from July to October (Figure 5) and in the Red Sea and Persian Gulf and Arabian Peninsula from October to December (Figure 6). Parasitoid releases should be an ideal complement to trapping as they are effective against the larval population, and the host searching abilities of the flies should ensure parasitation of larvae that might be undetectable by any means available at present. 


\section{Conclusions}

Even with the limited knowledge available, the potential of the Brazilian tachinid parasitoids for palm weevil control in areas beyond its natural range of occurrence is obvious. Research on the biology, chemical ecology and host range should demonstrate their potential for introduction biocontrol in other areas of the humid tropics and the possibility of use in controlled release operations in areas where the climatic conditions do not allow permanent establishment.

\section{Acknowledgements}

We are indebted to José Inacio Moura for his advice during the development of the research project and all the circumstantial evidence about parasitoid ecology. Rafael Reyes was instrumental in overcoming the legions of bureaucratic obstacles during project development. Jackeline Gaviria and Freddy Suarez conducted most of the weevil parasitation experiments with Billaea claripalpis, the sugarcane moth parasitoid, our model parasitoid, and Angela Castaño produced the maps of areas suitable for seasonal releases of the parasitoids in the Mediterranean and Near East/North Africa region. All are gratefully acknowledged.

\section{الملخص}

لور، برنهارد، ألاوماريو نيخريسولي وخوان بابلو مولينا. 2019. Billaea rhynchophorae، متطقل على سوسة النخيل بإمكانات عالمية. مجلة

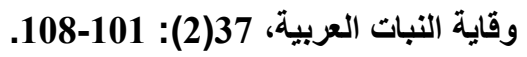

تعدّ سوسة النخيل الأمريكية Rhynchophorus palmarum الآفة الرئيسة الأساسية لأشجار النخيل والناقل الرئيسي للنيماتودا المسببة لمرض الحلقة الحمر اء

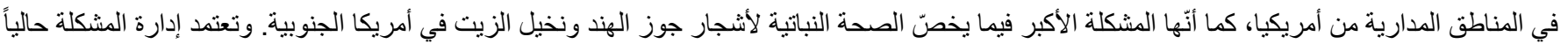
على اصطياد الحشر ات الكاملة للسوس باستخدام الفيرمونات التجميعية و إز الة النخلات المصابة، و هذا نظامٌ يصعب تطبيقه من قبل المزارعين ذوي الحياز ات الصغيرة. ومن بين عوامل المكافحة الحيوية للسوسة، يعرف ذباب التاكينيد. Billaea spp كمتطفل ذي انتشار محدود في ولاية باهيا البرازيلية؛ وإنّ عملية إدخاله و إطلاقه في المناطق المتضررة يمكن أن يعود بالنفع الكبير فيما يخصّ المكافحة الطبيعية لحشرات السوس. فضلاً عن ذلك، تعرف هذه المتطفلات بقدرتها على مهاجمة خمسة أجناس مختلفة من ثاقبات النخيل، ويمكن أن تكون خيار اً جديداً لمكافحة سوسة النخيل الحمر اء Rhynchophorus ferrugineus والتي تعدّ أسوا آفةٍ لأشجار النخيل في العالم. تتضوي أهداف هذا البحث على: جمع، وتربية، ودر اسة هذه المنطفلات لإدخالها إلى مناطق جديدة. وسيتم عرض تحليل مفصّل للخطو ات الضرورية للمواءمة مع الجوانب التشريعية، وبرنامج بحوث لضمان الأمان الحيوي.

كلمات مفتاحية: ســـوس النخيل، Rhynchophorus palmarum، Rerrugineus . منطفلات ذباب التاكينا، Billaea rhynchophorae، المدى العوائلي، تحليل المخاطر.

\section{References}

Aldana, R.C, J.A. Aldana, H. Calvache and P. Franco. 2010. Plagas de la palma de aceite en Colombia. Bogotá, Sena-Cenipalma, Convenio 0094 de 2009. Cuarta edición, 198 p.

Aldana, R.C, J.A. Aldana and O.M. Moya. 2011. Manejo del picudo Rhynchophorus palmarum L. (Coleoptera: Curculionidae). Cenipalma Bogotá, Colombia, 51 p.

Arnaud, P.H.Jr. 1978. A host parasite catalog of North American Tachinidae (Diptera). U.S. Department of Agriculture Miscellaneous Publication, 1319: 1-860.

Aman, 2001. Occurrence and damage caused by the red palm weevil, Rhynchophorus ferrugineus. Plant Protection, 55: 298-302 (in Jpn).

Azmi, W.A., Z. Chik, A.R.A. Razak and N.I.A. Ghani. 2013. A new invasive coconut pest in Malaysia: the red palm weevil (Curculionidae: Rhynchophorus ferrugineus). The Planter, 89: 97-110.

Baronio, P. and F. Sehnal. 1980. Dependence of the parasitoid Gonia cinerascens on the hormones of its lepidopterous hosts. Journal of Insect Physiology, 26: 619-626. https://doi.org/10.1016/0022-1910(80)90031-1
Barranco, P., J.A. de la Pena and T. Cabello. 1995. Un nuevo curculiónido tropical para la fauna Europea, Rhynchophorus ferrugineus (Olivier 1790), (Curculionidae: Coleoptera). Boletin de la Asociación Española de Entomologia, 20: 257-258.

Blanchard, E.E. 1937. Dipteros argentinos nuevos o poco conocidos. Revista de la Sociedad Entomologica Argentina, 9: 43-58.

Bobadilla, G.D. 1992 Unusual case of superparasitism in the Tachinidae (Diptera: Tachinidae) Acta Entomológica Chilena, 17: 241-244.

Bratti A. and W.C. Nettles. 1992. In vitro rearing of Eucelatoria bryani: improvements and evaluation of factors affecting efficiency. Entomologia Experimentalis et Applicata, 63: 213-219

Campadelli G. and G. Gardenghi. 1991. Note biologiche su Billaea triangulifera Zett. (Dipt. Tachinidae) parassitoide di Saperda scalaris L. (Col. Cerambycidae). Bolletino Istituto Entomológico "'Guido Grandi'" Univ Bologna, 45: 181-189

Cantrell, B.K. and R.W. Crosskey. 1989. Chapter 113. Family Tachinidae. In Evenhuis, N.C.(ed.) Catalog of 
the Diptera of the Australasian and Oceanian regions. Bishop Museum Press and E.J. Brill, Honolulu, HI.

Chinchilla, C.M. 1991. The red ring little leaf syndrome in oil palm and coconut palm. ASD Oil Palm Papers, 1: 1-17.

Clausen, C.P. 1940. Entomophagous Insects. Hafner Pub. Co, New York. 688 pp.

Clement, S.L., W.L. Rubink and D.A. McCartney. 1986 Larviposition response of Bonnetia comta (Diptera:Tachinidae) to a kairomone of Agrotis ipsilon (Lepidoptera: Noctuidae). Entomophaga, 31: 277-284. https://doi.org/10.1007/bf02373337

Crosskey, R. W. (1976). A Taxonomic Conspectus of the Tachinidae (Diptera) of the Oriental Region. Bulletin of the British Museum (Natural History) Entomology Supplement 26. 1-357.

Dindo, M.L. and S. Grenier. 2014 Production of Dipteran Parasitoids. In: Morales-Ramos, JA, Rojas, MG, Shapiro-Ilan, DI, eds. Mass Production of Beneficial Organisms: Invertebrates and Entomopathogens. London, England: Academic Press,101-143.

Dindo, M.L. 1998. Allevamento di Ditteri Tachinidi su diete artificiali. Atti Accad Naz Ital Entomol Rendiconti, 46: 105-133

Dindo, M.L., S. Grenier, L. Sighinolfi and P. Baronio. 2006. Biological and biochemical differences between in vitro and in vivo-reared Exorista larvarum. Entomologia Experimentalis et Applicata, 120: 167174. https://doi.org/10.1111/j.1570-7458.2006.00438.x

Dindo, M.L., E. Marchetti and P. Baronio. 2007. In vitro rearing of the parasitoid Exorista larvarum (Diptera: Tachinidae) from eggs laid out of host. Journal of Economic Entomology, 100: 26-30. https://doi.org/10.1093/jee/100.1.26

Eggleton, P. and R. Belshaw. 1993. Comparison of dipteran, hymenopteran, and coleopteran parasitoids: provisional phylogenetic explanations. Biological Journal of the Linnean Society, 48: 213-226. https://doi.org/10.1111/j.1095-8312.1993.tb00888.x

El-Sabea, M.R.A., J.R. Faleiro and M. Abo-El-Saad Mahmoud. 2009 The threat of red palm weevil Rhynchophorus ferrugineus to date plantations of the Gulf region in the Middle-East: Outlooks on Pest Management, 20: 131-134. https://doi.org/10.1564/20jun11

Fick, S.E. and R.J. Hijmans. 2017. Worldclim 2: New 1$\mathrm{km}$ spatial resolution climate surfaces for global land areas. International Journal of Climatology, 37: 43024315. https://doi.org/10.1002/joc.5086

Gross, H.R. 1988 Archytas marmoratus (Diptera: Tachinidae): Field survival and performance of mechanically extracted maggots. Environmental Entomology, 17: 233-237. https://doi.org/10.1093/ee/17.2.233

Gross, H.R., S.D. Pair and R.C. Layton. 1985 Archytas marmoratus (Diptera: Tachinidae): screen cage performance of mechanically extracted maggots against larval populations of Heliothis zea and Spodoptera frugiperda (Lepidoptera: Noctuidae) on whorl and tassel stage corn. Journal of Economic Entomology, 78: 1354-1357.

https://doi.org/10.1093/jee/78.6.1354

Hoddle, M.S., C.D. Hoddle, J.R. Faleiro, H.A.F. el-Shafie, D.R. Jeske and A.A. Sallam. 2015 How Far Can the Red Palm Weevil (Coleoptera: Curculionidae) Fly? Computerized Flight Mill Studies with Field-Captured Weevils. Journal of Economic Entomology, 108: 2599-2609. https://doi.org/10.1093/jee/tov240

Jones, P.G., W. Diaz and J.H. Cock. 2005 Homologue $^{\mathrm{TM}}$. A computer system for identifying similar environments throughout the tropical world. Centro Internacional de Agricultura Tropical Publication No. 342, CIAT, Cali, Colombia, 100 pp.

Ju, R.T. and A. Ajlan. 2011 Establishment and Potential Risks of a New Invasive Pest, Red Palm Weevil Rhynchophorus ferrugineus in China. Arab Journal of Plant Protection, 29: 122-130.

Kairo, M.T.K, A. Roda, R. Mankin, W. Chi, T. de, Damian, F. Franken, K. Heidweiller, C.Y. Johans, and J. Leon. 2010. The red palm weevil, Rhynchophorus ferrugineus, a nex pest threat in the C aribbean Food Crops Society 46th Annual Meeting and T-Star Invasive Symposium, July 11-17, 2010, Boca Chica, Dominican Republic, 87-96. Caribbean Food Crops Society, Isabela, Puerto Rico. English language.

Löhr, B. 2013. Biological control of palm weevils: rediscovering forgotten opportunities. Biocontrol News and Information, 34: 20N-23N.

Mellini, E. 1986 Importanza dello stadio dell' ospite, all momento de la parassitizzazione, per la biología dei ditteri larvevoridi. Frustula Entomologica, 7:1-23.

Mellini, E. and G. Campadelli. 1996. Formulas for "inexpensive", artificial diets for the parasitoid Exorista larvarum (L.) (Studies on Diptera Tachinidae. LXVIII contribution). Bolletino Istituto Entologico “'Guido Grandi', University of Bologna, 50: 95-106

Montieth, L.G. 1955. Host preferences of Drino bohemica Mesn. (Diptera:Tachinidae) with particular reference to olfactory responses. Canadian Entomologist, 87: 509-530. https://doi.org/10.4039/ent87509-12

Montieth, L.G. 1963. Habituation and associative learning in Drino bohemica Mesn. (Diptera:Tachinidae). Canadian Entomologist, 95: 418-426. https://doi.org/10.4039/ent95418-4

Moura, J.I.L., D. Mariau and J.H.C. Delabie. 1993. Efficacy of Paratheresia menezesi Townsend (Diptera: Tachinidae) for natural biological control of Rhynchophorus palmarum (L.) (Coleoptera: Curculionidae). Oléagineux, 48: 219-223.

Moura, J.I., C.J. Fanton and C.A.B. Mesquita. 2002. Evaluación de un método agronómico, biológico y químico para el combate de Amerrhinus ynca en plantaciones de coco. Manejo Integrado de Plagas y Agroecología (Costa Rica),65: 109-112.

Moura, J.I., R. Toma, R.B. Sgrillo and J.H.C. Delabie. 2006. Eficiência do parasitismo natural por Billaea rhynchophorae (Blanchard) (Diptera: Tachinidae) para o controle de Rhynchophorus palmarum (L.) (Coleoptera: Curculionidae). Neotropical Entomology, 35: 273-274. 
http://dx.doi.org/10.1590/S1519-

566X2006000200019

Moura, J.I.L. 2017. Manejo integrado das palmeiras. Ilhéus, BA, Brasil. CEPLAC/ESMAI. 186 pp.

Murphy, S.T. and B.R. Briscoe. 1999. The red palm weevil as an alien invasive: biology and the prospects for biological control as a component of IPM. Biocontrol News and Information, 20: 35N-46N.

Nihei, S.S. and P. Pavarini. 2011. Taxonomic redescription and biological notes on Diaugia angusta (Diptera, Tachinidae): parasitoid of the palm boring weevils Metamasius ensirostris and M. hemipterus (Coleoptera, Dryophthoridae). ZooKeys, 84: 23-38. https://doi.org/10.3897/zookeys.84.756

O'Hara, J.E. 1985. Oviposition strategies of the Tachinidae, a family of beneficial parasitic flies., University of Alberta Agriculture and Forestry Bulletin, 8: 31-34.

Ortega, L., E. Tabone, L. Beaudoin, D. Ment, M. Buradino, J.A. Jacas, I. Garrido, O. Dembilio and E. Quesada. 2017. Natural Enemies of Rhynchophorus ferrugineus and Paysandisia archon. Pages 171-186. In: Victoria Soroker, Stefano Colazza, ed., Handbook of Major Palm Pests. Biology and Management. GBR: John Wiley and Sons Ltd. 344 p., https://doi.org/10.1002/9781119057468.ch8

Posada, L., I. Zenner and F. Borrero. 1990. Notas y noticias entomológicas Septiembre-Octubre 1990. Instituto Colobiano Agropecuário, Tibaitatá, Bogotá, Colombia.

Ramirez F. 1998. Reconocimiento de enemigos naturales y estudio de la fluctuación poblacional de Rhynchophorus palmarum y Metamasius hemipterus (Coleoptera: Curculionidae) Acacías (Meta). Trabajo de grado para optar el título de Ingeniero Agrónomo. Universidad Nacional de Bogotá.

Rodriguez del Bosque, L.A. and J.W. Smith. 1996. Rearing and biology of Lydella jalisco (Diptera: Tachinidae), a parasite of Eoreuma loftini (Lepidoptera: Pyralidae) from Mexico. Annals of the Entomological Society of America, 89: 88-95. https://doi.org/10.1093/aesa/89.1.88

Roland, J., W.G.Y. Evans and J.H. Myers. 1989. Manipulation of oviposition patterns in the parasitoid
Cyzenis albicans (Tachinidae) in the field using plant extract. Journal of Insect Behaviour, 2: 487-503. https://doi.org/10.1007/bf01053350

Roth, J.P., E.G.Y. King and S.D. Hensley. 1982. Plant, host and parasite interactions in the host selection sequence of the tachinid Lixophaga diatraeae. Environmental Entomology, 11: 273-277. https://doi.org/10.1093/ee/11.2.273

Stireman, J.O, J.E. O’Hara and D.M. Wood. 2006. Tachinidae: Evolution, behavior and ecology. Annual Review of Entomology, 51: 525-555. https://doi.org/10.1146/annurev.ento.51.110104.1511 $\underline{33}$

Suazo, A., N. Arismendi, J.H. Frank and R.D. Cave. 2006. Method for continuously rearing Lixadmontia franki (Diptera: Tachinidae), a potential biological control agent of Metamasius callizona (Coleoptera: Dryophthoridae). Florida Entomologist, 89: 348-353. https://doi.org/10.1653/00154040(2006)89[348:mfcrlf]2.0.co;2

Terkanian, B. 1993. Effect of host deprivation on egg quality, egg load, and oviposition in a solitary parasitoid, Chetogena edwardsii (Diptera:Tachinidae). Journal of Insect Behavior, 6: 699-713. https://doi.org/10.1007/bf01201671

Thompson, S.N. 1999. Nutrition and culture of entomophagous insects. Annual Review of Entomology, 44: 561-592. https://doi.org/10.1146/annurev.ento.44.1.561

Vargas G., L.A. Gómez and J.P. Michaud. 2015. Sugarcane stem borers of the Colombian Cauca River Valley: current pest status, biology, and control. Florida Entomologist, 98: 728-735. https://doi.org/10.1653/024.098.0249

Vincent, L.S. 1985. The first record of a tachinid fly as an internal parasitoid of a spider Diptera: Tachinidae; Araneae: Antrodiaetidae). Pan-Pacific Entomologist, 61: 224-225.

Wood, D.M. 1987. Tachinidae. In: Manual of Nearctic Diptera Volume 2. J.F. McAlpine (ed.). Research Branch, Agriculture Canada. Monograph, 28: 11931269. 